\section{Олександр Потильчак}

доктор історичних наук, професор, завідувач кафедри джерелознавства та спеціальних історичних дисциплін Національний педагогічний університет імені М. П. Драгоманова (Київ, Україна)
Dr. hab. Prof. Oleksandr Potyl'chak Head of department of Original and Special Historical Sciences of the Faculty of History Education, National Pedagogical Dragomanov University (Kyiv, Ukraine)

pot1965@ukr.net

ORCID: https://orcid.org/0000-0003-3518-9280

ResearcherID: ABF-2675-2020

\title{
МАЛОВІДОМИЙ ТИП НАСЛІДУВАННЯ ДИРХЕМА 3 «КНЯЗІВСЬКИМ ЗНАКОМ» ВОЛОДИМИРА ОЛЬГЕРДОВИЧА
}

\section{THE UNKNOWN TYPE OF DIRHEM IMITATION WITH THE “KNIGHTS ‘SIGN” OF VOLODYMYR OLGERDOVYCH}

\section{Анотація.}

Мета статті полягає у введенні до наукового обігу, нумізматичному дослідженні та атрибуиії донедавна невідомого типу місцевих наслідувань дирхемів хана Токтамиша (1380-1399) карбування київського князя Володимира Ольгердовича (1362-1394). Автор розглядає обставини та географію знахідок, аналізує результати їх метрологічного дослідження, порушує питання про емітента, причини випуску цзього типу наслідування, період карбування, специфіку обігу, пропонує власну версію атрибуції «князівського знаку» на аверсі монет. Методологія дослідження окреслена принципами науковості, історизму, об'єктивності, методами аналізу, класифікації, узагальнення, історикогенетичним та історико-типологічним, методом штемпельного аналізу. Наукова новизна. Імовірним прототипом для наслідування міг бути дирхем хана Токтамиша карбування Сарая ал-Джадіда з датою 794. Пов'язати досліджувану емісію з іменем Володимира Ольгердовича дозволяє стилістична тотожність «князівського знаку» на аверсі монет із геральдичним елементом денаріїв изього князя. Присутня на монеті дата та історичні обставини змімення Володимира з киїського удільного столу дозволяють окреслити період карбування цуього типу монет 1392-1394 рр. Відомі на сьогодні знахідки дирхемів з «князівським знаком» локалізовано дугою вздовж лінії литовсько-татарського прикордоння в межах південних і східних теренів Київського удільного князівства та сусідніх північних територій Сіверщини. Головною метою емісій вважаємо економічні мотиви, а саме покриття дефіциту монетної маси на грошовому ринку прикордоння в межах Київського князівства. Участь даної емісії в торгівельних чи данницьких розрахунках з Ордою наразі недостатньо підтверджується нумізматичними джерелами, проте останнє не заперечує можливості спорадичного проникнення цих монет внаслідок переважно роздрібних торгово-грошових операщій на широкий простір литовсько-ординського прикордоння. Припускаємо, щзо однією з причин карбування Володимиром Ольгердовичем наслідувань даного типу могло бути спровоковане складними військово-політичними реаліями прагнення князя до ширшої політичної автономї й перегляду в майбутньому свого політичного статусу. Авторські 
спостереження дозволяють припустити стилістичний зв'язок «князівського знаку» на монетах із родовими гербами київських князів X-XI cm. Чітка просторова орієнтація изього геральдичного елементу на наслідуваннях дирхема спонукає до перегляду усталеної в нумізматиці думки щзодо просторової орієнтації «князівського знаку» на київських денаріях Володимира Ольгердовича. Висновки. Попередня атрибуція нумізматичної пам'ятки дає підстави стверджувати, щзо ми маємо справу з новим $і$ наразі малодослідженим у нумізматииі типом наслідування дирхем хана Токтамиша карбування київського князя Володимира Ольгердовича (1362-1394). Присутність на атрибутованій монеті «князівського знаку» може свідчити про офічійний характер емісії та ї̈ приналежність до регіональних регулярних наслідувань джучидських монет.

Ключові слова: Київське удільне князівство, Володимир Ольгердович, Токтамиш, дирхем, наслідування, «князівський знак».

\section{Abstract.}

The purpose of the article is to introduce into the scientific circulation, attribution and research until recently unknown to the numismatists, a rare and little-studied type of local imitation of Khan Toktamysh dirhems (1380-1399) of the minting of Prince Volodymyr Olgerdovych of Kyiv (1362-1394). The author examines the circumstances and geography of coin detection, analyses the results of metrological research of findings, raises questions about the eminent, the causes of this type of imitation, the period of minting, the specifics of circulation, and offers own version of the attribution of the "princely sign" on the obverse of the coins. The research methodology is outlined by the principles of scientific, historicism, objectivity, methods of analysis, classification, generalisation, historical-genetic and historical-typological, method of stamp analysis. Scientific novelty. A probable prototype for imitation could be the dirhem of Khan Toktamysh of the mint of Saray al-Jadid with the date 794. At present, four coins of this type engraved by one stamp for an obverse and two different stamps for reverse known from the numismatic literature. The main argument that allows us to link the investigated coinage with Volodymyr Olgerdovych is the stylistic identity of the "princely sign" on the obverse of imitation with the heraldic element known to the numismatists of the denariuses of that particular prince. The date (794 AD), which is present on the coin, as well as the historical circumstances of the displacement of Volodymyr from the Kyiv table by Grand Duke of Lithuania Vytautas Keistutovich, make it possible to outline the period of minting of this type of coins 1392-1394.

Comparison of metrological indicators of the studied coins, synchronous in time of regular coinage dirhems and previously known types of imitation, shows that dirhems with the "princely sign" occupy an intermediate place in this series, inferior to the weight and diameter of the Horde emissions, but far outweighed by these indicators, the known denariuses of Volodymyr Olgerdovych. The results of X-ray fluorescence analysis of the coin alloy showed $a$ very high silver content and low impurities of gold and copper. The oval shape of the coins indicates the use of "wire" coinage techniques and the relative accuracy of the reproduction of the Arabic text on the coin stamps proves their production by a professional, which is either understood in the Kufic font, or has seen a coin prototype. Mapping of places of detection of coins' imitations with the "princely sign" of Volodymyr Olgerdovych (along the broad line of the Lithuanian-Tatar border within the southern, eastern terrains of the Kyiv apanage principality and the neighbouring southern lands of the Principality of Siver). The numismatic sources introduced into the scientific circulation and the updated source information allow us to assume that economic motives were the primary purpose of the studied coinage. Namely, it 
was the filling of the local money market within the Kyiv principality by the coin mass. Existing numismatic sources do not sufficiently confirm the involvement of this mint in trading or paying tribute to the Horde. However, it does not deny the possibility of the sporadic penetration of Kyiv dirhem imitation with the "princely sign" into the vast expanses of the Lithuanian-Horde border, mainly through retail trade and money transactions. We suppose that one of the reasons for the coinage of this type of imitation by Volodymyr Olgerdovych could have been provoked by the complex military-political realities in the region, the prince's desire for broader political autonomy and revisiting in the future his status as a tribute and vassal in relations with the Horde and the Grand Duchy of Lithuania. The author's observations suggest stylistic connection of the "princely sign" of our coin with the generic emblems of the Kyiv princes of the $X$-XI centuries. The precise spatial orientation of this heraldic element on the coins studied makes it possible to raise the issue of revising the idea of the spatial orientation of the "princely sign" on the Kyiv denariuses of Volodymyr Olgerdovych. The Conclusions. A preliminary study and attribution of a numismatic monument discovered gives grounds to claim that we are dealing with a new, little-known and currently unknown type of imitation of the coins of Khan Toktamysh by PrinceVolodymyr Olgerdovych of Kyiv (1362-1394). The presence on the attributed coin a heraldic element in the form of a "princely sign" may indicate to the formalised coinage and its affiliation with the regular regional imitation of Juchid coins.

Keywords: Kyiv apanage principality, Volodymyr Olgerdovych, Toktamysh, dirhem, imitation, "princely sign".

Період правління у Києві удільного князя Володимира 3 литовської династії Ольгердовичів, який історіографічна традиція окреслює 1362-1394 pp., - наразі одна 3 найменше вивчених сторінок середньовічної української історії. Критична обмеженість і почасти суперечливість письмових джерел спонукають дослідників проблеми до якнайширшого залучення до контексту власних історичних студій нумізматичних пам'яток і даних нумізматики.

Монетне карбування Володимира Ольгердовича залишається предметом вивчення вже близько півтора століття. За цей період істориками й нумізматами відкрито, описано та атрибутовано більше десяти типів оригінальних монет і наслідувань, випуск яких приписується Володимиру. Запропоновано різні версії щодо хронології монетного карбування, статусу київського князя як монетного сеньйора, обставин виробництва та обігу київських монет у другій половині XIV ст. Уведені до наукового обігу ще B. Антоновичем ${ }^{1}$ та описані у класичній праці I. Толстого ${ }^{2}$ монети Володимира Ольгердовича пізніше досліджувалися К. Болсуновським ${ }^{3}$, М. Гумовським ${ }^{4}$, Н. Соболєвою ${ }^{5}$, М. Котляром ${ }^{6}$ та Ш. Бектінєєвим ${ }^{7}$.

Сучасний етап вивчення монетного карбування Київського князівства другої половини XIV ст. відбувається вже на новій, значно ширшій джерельній базі та охоплює не лише оригінальні монети Володимира Ольгердовича, але й наслідування ординських дирхем, карбування яких також пов'язують з іменем цього князя. Хронологію карбування

Антонович В. Б. О новонайденных серебряных монетах с именем Владимира. Труды III Археологического съезда (Киев, август 1874 г.). Т. II. Киев, 1878. С. 151-157.

2 Толстой И. И. Древнейшие русские монеты Великого княжества Киевского: нумизматический опыт. Санкт-Петербург: Типография Императорской академии наук, 1882. 272 c.

3 Болсуновский К. Монеты киевских князей XIV ст. Опыт историко-нумизматического исследования. Киев, 1909.16 с., табл.

${ }^{4}$ Gumowski M. Numizmatyka litewska wieków srednich. Wiadomości Numizmatyczno-Archeologiczne. 1921. XIX. S. 55-106.

${ }^{5}$ Соболева Н. А. К вопросу о монетах Владимира Ольгердовича (по нумизматическим материалам ГИМ). Нумизматика и эпиграфика. Москва, 1970. Вып. VIII. C. 81-87.

${ }^{6}$ Котляр Н. Ф. Клад монет Владимира Ольгердовича. Нумизматика и эпиграфика. 1970. Вып. VIII. С. 88-100; Котляр Н. Ф. Монеты Владимира Ольгердовича. Нумизматика и сфрагистика. Киев: Наукова думка, 1971. Вып. IV. C. 42-67.

Бектинеев Ш. Денежное обращение Великого княжества Литовского в XIII-XV вв. Минск: В. Н. Милютин, 1994.80 с. 
монет Київського князівства 1362-1394 рр. запропонував Г. Козубовський ${ }^{1}$ «Київські» наслідування джучидських монет XIV ст. вивчали К. Хромов та I. Хромова ${ }^{2}$, якій також належить чергова спроба атрибуції зображення родового знаку князів Ольгердовичів ${ }^{3}$. Пояснити передумови та причини карбування київських монет Володимира Ольгердовича суто економічними мотивами спробував С. Климовський ${ }^{4}$. Три примірники невідомих раніше монет із «князівським знаком» Володимира Ольгердовича, попередньо визначені як київські наслідування львівських напівгрошей Казимира III та Людовіка Угорського другої половини XIV ст., нещодавно були описані О. Погорільцем і Р. Саввовим. На підставі аналізу цього нечисленного нумізматичного матеріалу дослідники висунули припущення про вплив на формування традиції монетного карбування Київського князівства у другій половині XIV ст. не лише джучидської, але й європейської монети ${ }^{5}$. Висловлюючи скепсис щодо цієї думки колег, I. Хромова вважає описану ними емісію одним 3 нерегулярних місцевих наслідувань, про центр (або ж центри) карбування якого через недостатність нумізматичного матеріалу, на іiі думку, говорити зарано ${ }^{6}$. Протягом останніх років, практично, кожен пошуковий сезон приносить нові відкриття, а джерельна база оригінальних монет і наслідувань київського карбування другої половини XIV ст. динамічно поповнюється.

Мета даної статті - уведення до наукового обігу, дослідження та атрибуція донедавна невідомого й маловивченого нумізматами типу місцевих наслідувань дирхем (дангів) хана Токтамиша (1380-1399) карбування київського князя Володимира Ольгердовича (1362-1394). Автор розглядає обставини та географію виявлення монет, аналізує результати метрологічного дослідження знахідок, порушує питання про емітента, причини випуску цього типу наслідування, період карбування, специфіку обігу, пропонує власну версію атрибуції «князівського знаку» на аверсі монет.

Початок польового сезону 2018 р. приніс доволі несподіване відкриття. Група дослідників навчально-наукової лабораторії експертизи культурно-історичних цінностей кафедри джерелознавства та спеціальних історичних дисциплін історичного факультету Національного педагогічного університету імені М. П. Драгоманова7 під час обстеження ділянки ріллі на відстані 1-1,5 км західніше від села Вінницькі Стави Васильківського району на Київщині виявила, як спочатку здалося, звичайний золотоординський дирхем. Проведене пізніше камеральне дослідження дозволило попередньо атрибутувати знахідку як дирхем хана Токтамиша (1380-1399) карбування Сарая ал-Джадіда 3 датою 794 р. Х. (1391-1392 рр.). Утім, знайдена монета мала характерну особливість. На ії аверсі, вище

\footnotetext{
Козубовський Г. А. До хронології карбування монет Володимира Ольгердовича (1362-1394). Археологія. 2016. № 4. С. $27-41$.

2 Хромова I. До питання про вплив джучидської монетної традиції на формування місцевої монетної справи в українському Подніпров'ї середини другої половини XIV ст. Український історичний збірник. 2009. Вип. 12. С. 49-59; Хромова И., Хромов К. Вопросы атрибуции находок местных монет-подражаний второй половины XIV века на территории литовско-ордынского пограничья. Международная нумизматическая конференция. Вильнюс 23-25 мая 2012 г. Электронный pecypc. Режим доступа: www.hordecoins.folgat.net/Rpubl_Vilnus-conf-2012.htm; Хромова I. Монетне карбування на території Середнього Подніпров’я від наслідувань до офіційних емісій: питання іконографії. Український історичний збірник. 2012. Вип. 15. С. 229-237; Хромова І. До історії розвитку карбування на українських землях: місцеві наслідування джучидських монет XIV ст. Спеціальні історичні дисципліни: питання теорії та методики. Зб. наук. праць. Київ: НАН України, Інститут історії України, 2013. Ч. 22-23. С. 462-470; Хромов К., Хромова I. Місцеві монети-наслідування другої половини XIV ст. на литовсько-ординських прикордонних територіях. Ukraina Lithuanica. 2015. Т. 3. С. 191-203.

3 Хромова І. До проблеми атрибуції зображення родового знаку князів Ольгердовичів. Спеціальні історичні дисципліни: питання теорії та методики. Зб. наук. праць. Київ: НАН України, Інститут історії України, 2008. Ч. 15. С. 304-315; Хромова І. «Князівська символіка» у монетному карбуванні XIV - початку XV ст. 3 території Середнього Подніпров’я. Український історичний збірник. 2017. Вип. 19. С. 41-52.

${ }^{4}$ Климовський С. Київські монети Володимира Ольгердовича: пріоритет політики чи економіка? Історико-географічні дослідження в Україні. Київ, 2007. Вип. 10. С. 358-375.

5 Погорілець О., Саввов Р. Про нові монети зі знаком Володимира Ольгердовича. Нумізматика і фалеристика. 2009. № 1. С. 10-11; Саввов Р. Київські півгроші Володимира Ольгердовича. Нумізматика і фалеристика. 2012. № 4. С. 6-7.

6 Хромова І. К. Наслідування монет Червоної Русі з Середнього Подніпров'я. Спеціальні історичні дисципліни: питання теорії та методики. Збірка наукових праць. 2011. № 18. С. 224.

Навчально-наукова лабораторія експертизи культурно-історичних цінностей кафедри джерелознавства та спеціальних історичних дисциплін історичного факультету Національного педагогічного університету імені М. П. Драгоманова створена у 2013 р. Співробітники лабораторії забезпечують практичну підготовку студентів спеціалізації «Експертиза культурно-історичних цінностей», здійснюють експертизу предметів історичних і культурних цінностей, а також проводять наукові дослідження у предметній сфері спеціальних галузей історичної науки. У 2017 р. лабораторією започатковано науковий проект постійно діючої польової нумізматичної експедиції за темою: «Грошовий обіг Правобережної України у XVI - XVIII ст. (регіон Південної Київщини та Середнього Поросся)».
} 
від зазначених титулу та імені хана, розміщено князівський знак, добре відомий нумізматам на монетах київського князя Володимира Ольгердовича (1362-1394)1.

Пошуки аналогій серед знахідок джучидських монет та їхніх наслідувань дали підстави говорити про те, що виявлена поблизу Вінницьких Ставів монета належить до маловідомих i, практично, недосліджених у нумізматиці наслідувань дирхема хана Токтамиша карбування київського князя Володимира Ольгердовича (1362-1394). Принаймні, так атрибутують монету iii перші публікатори - російські нумізмати О. Тростьянський та Б. Леонов ${ }^{2}$. Намагаючись знайти підтвердження цій гіпотезі, ми порівняли легенди знайденої нами монети з легендами каталогізованих емісій дирхемів Золотої Орди, описаних у праці Р. Сагдєєвої (2005). Наразі ймовірним прототипом для наслідування міг бути дирхем хана Токтамиша карбування Сарая ал-Джадіда 3 датою 794, що зазначений у впорядкованому дослідницею каталозі під номером $413^{3}$.

Наслідування виготовлене зі срібла, має вагу 0,87 г і діаметр 13,53-15,54 мм. На аверсі карбівки - оточений хвилястим рантом скорочений напис арабською мовою, розміщений трьома рядками: السلطان / توكتاميش / خان (Султан/ Токтамиш/ хан). Над верхнім рядком (скорочене написання титулу - «Султан») розміщено князівський знак Ольгердовичів. Реверс містить скорочений текст арабською мовою: Vqץ / (Карбовано / ал-Джадід / 794), так само обрамлений хвилястим рантом. Незважаючи на втрату невеликої частини поля монети, пам'ятка досить непогано збереглася, іiі легенди та зображення «князівського знаку» розбірливі та добре читаються [Див.: рис. 1].

До цієї публікації у нумізматичній літературі було описано лише дві такі монети, а дані про виявлення ще однієї ми отримали приватно вже під час підготовки цього дослідження. Наразі, окрім нашої знахідки, автору відомо три примірники цього типу наслідування дангів Токтамиша. Першу таку монету знайшли в Україні, проте обставини та локація знахідки так і залишилися нез'ясованими. Маємо лише іiї зображення [Див.: рис. 2]. Інша раніше описана монета була частиною великого скарбу, виявленого на початку 2000-х рр. у Клімовському районі Брянської області Російської Федерації. Серед 1185 монет цієї тезаврації абсолютну більшість становили дирхеми Токтамиша, карбовані на різних монетних дворах Золотої Орди. Близько сотні дирхемів скарбу належать ханампопередникам. Дирхем Токтамиша карбування Сарая ал-Джадіда 3 датою 794 (р. Х.) i князівським знаком Ольгердовичів виявився у цьому скарбі єдиним [Див.: рис. 3] ${ }^{4}$.

Третя з відомих нам монет також була виявлена в Україні та досі залишалася неопублікованою. За допомогою колег ${ }^{5}$ авторові вдалося отримати деяку інформацію про цю знахідку, локалізовану в Хорольському районі Полтавщини у складі невеликого комплексу синхронних у часі монет. Окрім наслідування дирхема Токтамиша вагою 0,85 грама 3 «князівським знаком» Ольгердовичів на кількох квадратних метрах у місці знахідки пошуковцем було підібрано близько десятка інших наслідувань золотоординських данг та кілька денаріїв Володимира Ольгердовича. Візуальне дослідження реверсу цієї монети дозволяє помітити відмінність ії штемпеля від штемпеля

\footnotetext{
Наслідування дирхему хана Тохтамиша карбування Сарая ал-Джадіда 794 р. х. (1391-1392 р.). Інв. № 33. Архів Навчально-наукової лабораторії експертизи культурно-історичних цінностей кафедри джерелознавства та спеціальних історичних дисциплін Національного педагогічного університету імені М. П. Драгоманова [далі - Архів ННЛ ЕКІЦ НПУ імені М. П. Драгоманова], м. Київ. Фонд 2. Польові описи експедицій [Field descriptions of expeditions]. Опис 1. Справа 1. Польовий опис постійно діючої нумізматичної експедииії за темою «Грошовий обіг Правобережної Украӥни у XVI-XVIII cm.cm. (регіон Південної Київини та Середнього Поросся)». [Field description of a permanent numismatic expedition on the topic «Money circulation of Right-Bank Ukraine in the 16th - 18th centuries. (region of South Kyiv region and the Middle Porossiya)»]. 2016-2018 рр. Арк. 10.

2 Тростьянский О. В., Леонов Б. И. Новый тип монет Киевского княжества конца XIV века. Нумизматика Золотой Орды: Научный ежегодник 2016. № 6. C. 95-97, 156.

3 Сагдеева Р. 3. Серебряные монеты ханов Золотой Орды. Москва, 2005. С. 47.

4 Тростьянский О. В., Леонов Б. И. Указ. ст. С. 95.

Автор висловлює щиру вдячність нумізмату-медієвісту з м. Чебоксари (Російська Федерація) Олегу Вікторовичу Тростьянському за безкорисно надану інформацію про обставини виявлення, метрологічні показники монети, знайденої в Хорольському районі Полтавщини та світлини ії сторін. Ми також вдячні Оксані Валеріївні Тростьянській за зроблені нею графічні реконструкції штемпелів аверсу та реверсу монет досліджуваного типу.
} 
реверсу трьох інших відомих нам монет, які виглядають абсолютно ідентичними. Вперше на цю обставину звернув увагу О. Тростьянський у нашому 3 ним електронному листуванні. «[...] Як бачите, - пише дослідник, - тепер відомі два штемпеля зворотного боку (другим штемпелем карбовано монету з Полтавщини), що свідчить про те, що емісія не була мінімальною та, як мінімум, один штемпель був зношений» [Див.: рис. 4].

Обмежена кількість відомих нумізматам поодиноких і випадкових знахідок монет цього типу (4 примірники) не дає наразі підстав для широких узагальнень, проте все ж дозволяє порушити кілька важливих питань щодо їх емітента, передумов і причин випуску наслідувань цього типу монет, періоду їх карбування, локалізації регіону обігу та специфіки останнього. Зрештою, важливі дані для атрибуції окресленого типу монет може надати дослідження іконографії «князівського знаку» на аверсі наслідувань.

Ключовим питанням у контексті атрибуції описуваного типу наслідувань дирхемів виступає визначення емітента. Автори першої їх публікації (О. Тростьянський та Б. Леонов) пов’язують карбування монет 3 іменем київського князя Володимира Ольгердовича. Головний аргумент на користь цієї думки - очевидна стилістична тотожність «князівського знаку» на аверсі нововиявлених наслідувань з геральдичним елементом, що присутній на добре відомих нумізматам денаріях з іменем Володимира, вперше атрибутованих ще В. Антоновичем у 1878 р. Не менш вагомою підставою, яка дозволяє пов'язувати емісію саме з іменем цього удільного київського князя, виступає присутня на монеті дата - 794 р. Х. Ця дата, вочевидь, скопійована 3 монети-прототипу, практично, не залишає сумнівів у тому, що даний тип наслідування не міг карбуватися раніше 1392 р. Складніше визначити можливу верхню дату емісії. Тут ми вже не можемо уникнути певних припущень. Якщо вважати «князівський знак» на монетах таким, що належить саме Володимиру Ольгердовичу, то верхня межа їх карбування не могла сягати часу пізніше осені 1394 р., коли великий князь литовський Вітовт змістив Володимира 3 удільного київського столу1. За такою логікою період карбування цього типу київських наслідувань міг бути відносно тривалим - від одного до двох років. На користь такого висновку свідчить і незаперечний факт наявності, як мінімум, двох варіантів штемпелів реверсу монети [Див.: рис. 5].

Важливі дані про характер емісії може надати аналіз метрологічних показників, елементного складу лігатурного сплаву а також технологічних особливостей виготовлення штемпелів досліджуваних монет. Автору відома вага трьох і діаметр двох iз чотирьох відомих нумізматам монет цього типу [Див.: рис. 1. Вага - 0,87 г; діаметр 13,53-15,54 мм²; рис. 3. Вага - 0,93 г; діаметр - 15,0-17,2 мм³; рис. 4 Вага - 0,85 $\Gamma^{4}$. Порівняння цих показників з показниками ваги синхронних у часі дирхемів хана Токтамиша регулярного карбування та інших раніше відомих нумізматам наслідувань, показує, що досліджувані нами монети дещо поступаються вагою власне ординським емісіям $\left(1,3-1,49\right.$ г) ${ }^{5}$, проте вони значно важчі за відомі денарії Володимира Ольгердовича 3 «князівським знаком» $(0,18-0,36 \text { г })^{6}$.

Форма всіх відомих наслідувань цього типу овальна, що є ознакою застосування при виготовленні монет поширеної на той час в Орді, руських і литовських землях «дротової» техніки карбування. Цікава деталь. Розміщення елементів «князівського знаку» (тамги) на аверсі монети - зміщення «нижнього хреста» праворуч - може свідчити про те, що сам знак вирізувався на штемпелі вже після того, як було вирізано його

\footnotetext{
Котляр Н. Ф. Монеты Владимира Ольгердовича. Нумизматика и сфрагистика. Киев: Наукова думка, 1971. Вып. IV. C. 44.

2 Архів ННЛ ЕКІЦ НПУ імені М. П. Драгоманова. Фонд 2. Опис 1. Справа 1. Арк. 10.

Тростьянский О. В., Леонов Б. И. Указ. ст. С. 95.

4 За даними О. Тростьянського.

Федоров-Давыдов Г. А. Денежное дело Золотой Орды. Москва: Палеограф, 2003. С. 15-16.

Котляр Н. Ф. Монеты Владимира Ольгердовича. Нумизматика и сфрагистика. Киев: Наукова думка, 1971. Вып. IV. C. 54.
} 
арабську легенду. Припускаємо, що рішення про розміщення на монеті власного геральдичного знаку замовник штемпелів прийняв для себе не відразу, а вже у процесі або навіть після їх виготовлення [Див.: рис. 5.1]. Відносна акуратність, з якою різьбяр відтворив арабський текст на монеті-наслідуванні, може свідчити про те, що автором штемпелів міг бути професійний монетник, який або розумівся на куфічному шрифті, або ж, принаймні, бачив монету-прототип.

Результати радіо-флуоресцентного аналізу (РФА) лігатурного сплаву наслідування, знайденого поблизу Вінницьких Ставів (виконаний за допомогою приладу «Ехреrt Mobile») показали, що монета виготовлена зі срібла дуже високої проби, а монетний сплав також містить невеликі домішки золота та міді [Див.: табл. 1]. Такий склад лігатурного сплаву дозволяє з обережністю говорити про те, що у процесі виробництва монет майстри могли використовувати не стільки продукти переплавки зношеного монетного срібла та інших виробів з нього, скільки імпортовану рудну сировину. Проте слід враховувати, що неоднорідність давніх монетних сплавів здатна суттєво впливати на показники РФА, які можуть значно відрізнятись у різних точках поля поверхні досліджуваної монети ${ }^{1}$.

Таблиця 1.

Показники радіо-флуоресцентного аналізу (РФА) лігатурного сплаву наслідування дирхема з Вінницьких Ставів Васильківського р-ну Київської обл.

\begin{tabular}{|c|c|c|c|c|}
\hline \multicolumn{2}{|c|}{ Метрологічні показники } & \multicolumn{3}{|c|}{ Елементи лігатурного сплаву монети (у \%) } \\
\hline Вага (г) & Діаметр (мм) & $29 \mathrm{Cu}$ & $47 \mathrm{Ag}$ & $79 \mathrm{Au}$ \\
\hline 0,87 & $13,53-15,54$ & $0,125 \pm 0,012$ & $99,624 \pm 0,019$ & $0,251 \pm 0,014$ \\
\hline
\end{tabular}

Картографування місць виявлення наслідувань дирхема Токтамиша 3 «князівським знаком» Володимира Ольгердовича показує, що дві з трьох відомих нумізматам знахідок монет цього типу локалізуються саме на порубіжних з Ордою історичних землях удільного Київського князівства кінця XIV - початку XV ст., на півдні сучасних Київської та Полтавської областей. Третю монету знайдено на північ від князівства, у межах сусідньої Сіверської землі. Наразі знахідки утворюють своєрідну дугу вздовж широкої лінії литовсько-татарського прикордоння в лісостеповій зоні Середнього Подніпров'я, Лівобережжя та Сіверського Полісся [Див.: рис. 6].

Намагаючись розібратися з причинами карбування Володимиром Ольгердовичем протягом останніх років свого правління у Києві наслідувань дирхем Токтамиша із власним «князівським знаком», маємо враховувати не лише обставини функціонування грошового ринку Подніпров'я другої половини XIV ст., але й політичну ситуацію 1390-х pp. у Великому князівстві Литовському (ВКЛ) та Орді. Увійшовши до складу ВКЛ після 1362 р., землі Київського князівства протягом усієї другої половини століття продовжували залишатися під домінуючим політичним та економічним впливом Орди. Одним із проявів такого впливу була активна участь джучидських монет у грошовому обігу литовсько-ординського прикордоння. На думку української дослідниці І. Хромової, саме ця обставина стала головною передумовою активного розвитку на Подніпров’і власного монетного виробництва ${ }^{2}$. К. Хромов та І. Хромова пов'язують активізацію київського монетного карбування у другій половині XIV ст. 3 демографічними та

Потильчак О. В. Неописаний тип наслідування Джучидським дирхемам кінця XIV століття: до проблеми атрибуції нумізматичної пам'ятки. Наукова атрибуція творів мистецтва, експертиза та оцінка культурних цінностей : матеріали наук.-практ. конф., (м. Київ, $24-25$ жовтня 2019 р.). Київ: НАКККІМ, Асоціація мистецтвознавців, експертів, оцінювачів та реставраторів, 2019. С. 121-122.

2 Хромова I. До історії розвитку карбування на українських землях: місцеві наслідування джучидських монет ХІV ст. Спеціальні історичні дисципліни: питання теорії та методики. 3б. наук. праць. Київ: НАН України, Інститут історії України, 2013. Ч. 22-23. С. 462. 
економічними наслідками світової пандемії чуми 1347-1353 рр., яка спричинила занепад звичних торгівельних шляхів та переорієнтацію вектора економічної активності 3 Північного Причорномор'я та Криму на Середнє Подніпров'я. У цій логіці досить обгрунтованим виглядає припущення науковців про те, що основним призначенням місцевих регулярних наслідувань ординським монетам було «[...] насичення регіональних ринків дрібною срібною монетою $[.].\rangle^{1}$. Попри те, що наведений висновок дослідників стосувався більш ранніх київських наслідувань дангів Джанібека, все ж вважаємо його справедливим і в нашому випадку.

Дещо іншої думки щодо економічних причин карбування київським князем наслідувань дирхема Токтамиша 3 датою 794 р. Х. притримуються російські нумізмати О. Тростьянський та Б. Леонов. Дослідники припускають, що дана емісія була викарбувана Володимиром Ольгердовичем з метою забезпечення «[...] розрахунків із контрагентами за межами князівства, для яких «схудлі» та низькопробні місцеві «пенязи» були незручними для розрахунків [...]». Непрямим підтвердженням свого припущення дослідники називають факт виявлення однієї такої монети у скарбові ординських дирхемів з Клімовського району Брянської області РФ, тобто, відносно далеко і зовсім поза межами історичної території Київського князівства².

Ми вважаємо такий висновок колег дещо передчасним, адже одинична знахідка київського наслідування дирхема Токтамиша з «князівським знаком» у складі скарбу інших, синхронних у часі джучидських монет, не може слугувати переконливим аргументом на користь участі подібних емісій у торгівельних чи данницьких («вихід») розрахунках з Ордою. Останнє не заперечує можливості спорадичного проникнення та розповсюдження, внаслідок переважно роздрібних торгово-грошових операцій, наслідувань дирхемів київського карбування 1392-1394 рр. на широкому просторі литовсько-ординського прикордоння.

Враховуючи уведені до наукового обігу нумізматичні джерела та обсяг актуалізованої джерельної інформації, наразі маємо солідаризуватися з І. Хромовою та припустити, що головне призначення досліджуваної емісії полягало у наповненні монетною масою передусім місцевого грошового ринку прикордоння в межах Київського князівства. Непрямим підтвердженням такої нашої думки виступає локалізація знахідки. Наслідування дирхема виявлено на південь від Києва, на лівобережжі Середнього Поросся, що в досліджуваний період входило до складу Київського князівства та безпосередньо прилягло до володінь Орди у Подніпров’і. Це наше припущення потребує верифікації на основі ширшого джерельного нумізматичного матеріалу, який наразі відсутній.

Не менш важливим чинником, що сприяв появі на порубіжних землях ВКЛ квазіавтономного карбування, орієнтованого на джучидські традиції монетного виробництва, дослідники називають послаблення центральної ханської влади в Орді та відповідне посилення місцевих правителів на їі кордонах ${ }^{3}$. I справді, період карбування цього типу наслідувань 3 «князівським знаком» Володимира Ольгердовича припадає на час політичної турбулентності в регіоні. У 1385-1392 рр. тривала боротьба за владу в литовських землях між королем Польщі Владиславом Ягайлом (якому присягав на вірність і якого підтримав збройно Володимир Ольгердович) та Вітовтом Кейстутовичем ${ }^{4}$. Нетривалий період політичної стабільності в Орді протягом 1391-1395 рр. змінився запеклим військовим протистоянням між ханом Улусу Джучі Токтамишем та еміром

\footnotetext{
Хромов К., Хромова I. Місцеві монети-наслідування другої половини XIV ст. на литовсько-ординських прикордонних територіях. Ukraina Lithuanica. 2015. T. 3. C. 198

2 Тростьянский О. В., Леонов Б. И. Указ. соч. С. 96.

3 Тростьянский О. В., Леонов Б. И. Указ. соч. С. 97.

${ }^{4}$ Русина О. В. Україна під татарами і Литвою. Київ: Видавничий дім «Альтернативи», 1998. С. 66.
} 
Тамерланом ${ }^{1}$. Припускаємо, що ці несприятливі як для литовського, так і для ординського сюзеренів Володимира Ольгердовича військово-політичні обставини могли спонукати удільного київського князя до активніших кроків у напрямку розширення автономності, певної корекції свого статусу васала у відносинах з Ордою та ВКЛ. Одним із таких кроків цілком могло бути карбування дирхемів з іменем Токтамиша й київським «князівським знаком» на аверсі. Присутність на опублікованій тут монеті (як і на інших, відомих нумізматам одноштемпельних примірниках) «князівського знаку» може свідчити про офіційний характер даної емісії та іiі приналежність до регіональних регулярних наслідувань джучидських монет. «Князівський знак» (у джучидській традиції - «тамга») тут виступає хоч і додатковим, але все ж самостійним геральдичним елементом даного монетного типу. Шукаючи логіку у такому кроці емітента - київського удільного князя, можемо припустити, що Володимир визнавав залежність від Токтамиша та, зважаючи на замирення Ягайла з Вітовтом (Острівська угода, 1392 р.), сподівався на підтримку великого хана у своєму неминучому конфлікті з намісником польського короля у ВКЛ.

Важливу проблему становить атрибуція «князівського знаку» на монетах описуваного типу. Йдеться, передусім, про його стилістичну подібність із протогеральдичним знаком на денаріях Володимира Ольгердовича, просторову орієнтацію останнього, пропорції та деяку візуальну схожість 3 варіантами родового герба Рюриковичів домонгольського періоду. Зазначимо, що перші спроби інтерпретації протогеральдичного елементу на монетах Володимира Ольгердовича зробив ще В. Антонович, який доводив його генетичний зв’язок із гербом литовських князів типу «колюмни»². Схожий підхід до атрибуції «князівського знаку» застосував Н. Петров, трактуючи його як зображення Золотих Воріт Києва ${ }^{3}$. Цей ряд «архітектурних» трактувань геральдичного знаку Володимира Ольгердовича продовжують сучасні білоруські нумізмати Д. Гулєцкій та К. Петрунін, котрі доволі очікувано розгледіли в ньому «каплицю» ${ }^{4}$. Близький до цієї думки варіант «церкви» розглядають як небезпідставний Г. Козубовський та С. Климовський ${ }^{5}$.

Частина дослідників монет Володимира Ольгердовича пов'язували «князівський знак» із геральдичною традицією давньоруських Рюриковичів. Зокрема, І. Толстой намагався побачити в цьому геральдичному елементі хоругву київських князів домонгольського періоду ${ }^{6}$. Його точку зору частково поділяв М. Гумовський ${ }^{7}$. Спадковий зв'язок «князівського знаку» Володимира Ольгердовича 3 гербами київських i чернігівських Рюриковичів простежував К. Болсуновський ${ }^{8}$.

Частина вчених, які в різні періоди вивчали окреслену проблему, не пов’язують безпосередньо стилістику князівського знаку на монетах Володимира Ольгердовича 3 якоюсь конкретною геральдичною традицією, а визначають його або як оригінальний родовий герб Ольгердовичів (В. Шугаєвський ${ }^{9}$, I. Хромова ${ }^{10}$ ), або ж як знак київського князя Володимира з цієї ж династії (М. Гумовський ${ }^{11}$, А. Ільїн ${ }^{12}$ ).

\footnotetext{
Черкас Б. Західні володіння Золотої Орди в 1380-1399 рр. (політичний аспект). Україна в Центрально-Східній Свропі. Ред. кол.: В. Смолій (відп. ред.). НАН України. Інститут історії України; Український національний комітет з вивчення країн Центральної і Південно-Східної Європи. Вип. 12-13. Київ: Інститут історії України, 2013. С. 197-204.

Антонович В. Б. Указ. соч. С. 156-157.

3 Петров Н. И. О новооткрытой киевской монете XIV века. Сборник Харьковского историко-филологического общества. Т. VIII. Харьков: «Печатное дело», 1908. С. 6.

${ }^{4}$ Гулецкий Д. В., Петрунин К. М. Русские монеты 1353-1533. Каталог. Минск: РИФТУР, 2013. С. 300.

${ }^{5}$ Козубовский Г. А. Находки монет на территории Киева. Киев, 1991. С. 15; Климовський С. Вказ. ст. С. 372.

6 Толстой И. И. Указ соч. С. 221.

Gumowski M. Numizmatyka litewska wieków srednich. Wiadomości Numizmatyczno-Archeologiczne. 1921. XIX. S. 66-67.

${ }^{8}$ Болсуновский К. В. Монеты киевских князей XIV столетия. Киев: Типо-литография «Прогресс», 1909. С. 7-10.

9 Хромова І. До проблеми атрибуції зображення родового знаку князів Ольгердовичів. Спеціальні історичні дисципліни: питання теорії та методики. Зб. наук. праць. Київ: НАН України, Інститут історії України, 2008. Ч. 15. С. 305.

${ }_{10}$ Там само. С. 309.

11 Соболева Н. А. Указ. соч. С. 83

12 Ильин А. А. Классификация русских удельных монет. Ленинград: Гос. Эрмитаж, 1940. С. 19-20.
} 
Оригінальне трактування змістового наповнення князівського знаку на монетах Володимира Ольгердовича свого часу запропонував М. Котляр. Заперечивши версію К. Болсуновського про спадковість князівського знаку Ольгердовичів від київськочернігівської геральдичної традиції, вчений припустив, що знак «[...] був створений спеціально для цього князя та представляє своєрідну монограму 3 літер К та В, початкових літер слів «Київ» i «Володимир». Дійсно, якщо повернути монету Володимира Ольгердовича на $90^{\circ}$ проти годинникової стрілки, то у князівському знакові ми прочитаємо літери К та В» ${ }^{1}$. Критика М. Котляром точки зору К. Болсуновського та його однодумців грунтувалася на двох простих аргументах. Перший із них очевидний Володимир Ольгердович не був Рюриковичем. Що стосується другого аргументу, то він не такий однозначний, оскільки грунтується на стереотипному уявленні про «правильну» просторову орієнтацію князівського знаку на київських денаріях Володимира Ольгердовича, яке з часу першої публікації цих монет В. Антоновичем утвердилося в російській і вітчизняній нумізматиці. М. Котляр так прокоментував цей свій аргумент: «[...] Відомі науці родові знаки Рюриковичів X - першої половини XII ст. зовсім не схожі на розглядувану тут фігуру, і навряд чи остання могла розвинутися із цих знаків. Щоб припустити трансформацію одного зі знаків Рюриковичів у фігуру на монетах Володимира, останню довелося б повернути «вниз головою», що неможливо через іiі (фігури - Авт.) чітку орієнтацію положенням обох окреслених у ній хрестів [...]»². Ми навмисне навели цю аргументацію відомого вітчизняного вченого-нумізмата повністю, адже, будучи опублікованою ще на початку 1970-х рр., вона безпосередньо стосується атрибуції «князівського знаку» на аверсі нещодавно виявлених наслідувань дирхема Токтамиша карбування Володимира Ольгердовича.

Визначена арабською легендою на монетах фактична просторова орієнтація «князівського знаку» [Див.: рис. 1-3] не залишає сумнівів, що геральдичний елемент зорієнтований зовнішнім хрестом донизу (на це вказували вже О. Тростьянський та Б. Леонов ${ }^{3}$ ) та має видовжені пропорції, які нагадують «тризуб» 3 центральним «зубом» у вигляді хреста [Див.: рис. 4].

Ці спостереження дозволяють авторові припустити певний стилістичний зв'язок «князівського знаку» нашої монети з родовими гербами київських князів X-XI ст., які присутні, зокрема, на монетах і печатках Володимира Святославича, Святополка Володимировича та Ярослава Мудрого. Уведені до наукового обігу нові нумізматичні джерела дозволяють порушити питання про перегляд усталеної в нумізматиці думки щодо просторової орієнтації «князівського знаку» на київських денаріях Володимира Ольгердовича.

Важливим питанням, що потребує пояснення, залишається питання мотивації Володимиром Ольгердовичем вибору геральдичної основи для «князівського знаку» на своїх монетах. Цілком логічною виглядає позиція О. Тростьянського та Б. Леонова, які припускають, що таким чином Ольгердовичі намагалися підкреслити спадковість своєї влади від Рюриковичів ${ }^{4}$. Очевидно, тут ми спостерігаємо певну претензійність нового київського князя з литовської династії Ольгердовичів на державницьку спадщину Русі. Цілком можливо, що понад 300-літня історія києво-руської державності та колишній стольний статус Києва вочевидь могли стати для Володимира Ольгердовича переконливими мотивами для того, аби підкреслювати наступність своєї влади від київських Рюриковичів, і це попри визнання верховної влади Токтамиша та васальної залежності від великого литовського князя і короля польського.

\footnotetext{
Котляр Н. Ф. Монеты Владимира Ольгердовича. Нумизматика и сфрагистика. Киев, 1971. Вып. IV. С. 50.

${ }^{2}$ Там же.

3 Тростьянский О. В., Леонов Б. И. Указ. соч. С. 96

${ }^{4}$ Там же.
} 
Отже, попереднє дослідження та атрибуція нумізматичної пам'ятки, виявленої навесні 2018 р. поблизу Вінницьких Ставів Васильківського району Київської області, дає підстави стверджувати, що ми маємо справу 3 новим, маловідомим і наразі малодослідженим у нумізматиці типом наслідування дангів хана Токтамиша карбування київського князя Володимира Ольгердовича (1362-1394). Присутність на атрибутованій монеті геральдичного елементу у вигляді «князівського знаку» може свідчити про офіційний характер цієї емісії та іiі приналежність до регіональних регулярних наслідувань джучидських монет. Імовірним прототипом для наслідування міг бути дирхем хана Токтамиша карбування Сарая ал-Джадіда 3 датою 794. Наразі 3 нумізматичної літератури відомо 4 наслідування даного типу, викарбувані одним штемпелем аверсу та двома штемпелями реверсу.

Головний аргумент, який дозволяє пов'язати досліджувану емісію 3 іменем Володимира Ольгердовича, - стилістична тотожність «князівського знаку» на аверсі наслідувань із геральдичним елементом відомих нумізматам денаріїв цього удільного князя. Присутня на монеті дата (794р. Х.) а також історичні обставини зміщення Володимира 3 київського удільного столу великим князем литовським Вітовтом Кейстутовичем дозволяють окреслити період карбування даного типу монет 13921394 pp.

Порівняння метрологічних показників досліджуваних монет, синхронних у часі дирхемів регулярного карбування та раніше відомих типів наслідувань показує, що дирхем з «князівським знаком» посідає проміжне місце у цьому ряду, поступаючись вагою та діаметром власне ординським емісіям, але значно переважаючи за цими показниками відомі денарії Володимира Ольгердовича. Результати РФА аналізу поверхового шару монетного сплаву показали дуже високий вміст срібла та невеликі домішки золота й міді в лігатурі. Овальна форма монет свідчить про застосування «дротової» техніки карбування, а відносна акуратність відтворення арабського тексту на штемпелях монети може свідчити про їх виготовлення професійним монетником, який або розумівся на куфічному шрифті, або ж бачив монету-прототип.

Картографування місць виявлення наслідувань із «князівським знаком» Володимира Ольгердовича показує їх локалізацію у формі дуги вздовж широкої лінії литовсько-татарського прикордоння в межах південних і східних теренів Київського удільного князівства та сусідніх північних територій Сіверщини. Враховуючи введені до наукового обігу нумізматичні джерела та обсяг актуалізованої джерельної інформації, припускаємо, що головною метою емісії досліджуваного типу було наповнення монетною масою місцевого грошового ринку прикордоння в межах Київського князівства. Участь даної емісії в торгівельних чи данницьких розрахунках з Ордою наразі недостатньо підтверджується нумізматичними джерелами, проте останнє не заперечує можливості спорадичного проникнення київських наслідувань дирхема 3 «князівським знаком» на широкий простір литовсько-ординського прикордоння внаслідок переважно роздрібних торгово-грошових операцій,

Не виключено, що однією з причин карбування Володимиром Ольгердовичем наслідувань даного типу могло бути спровоковане складними військово-політичними реаліями в регіоні прагнення князя до ширшої політичної автономії а також перегляду в майбутньому свого статусу данника й васала у відносинах з Ордою та ВКЛ. Рішення розмістити власний «князівський знак» на монеті з ім'ям Токтамиша, мабуть, давалося Володимиру Ольгердовичу непросто. Свідчення тому - характер виконання цього знаку на вже готовому штемпелі, коли майстер дорізав його до основного зображення. 
Наші спостереження дозволяють припустити наявність певного стилістичного зв'язку «князівського знаку» на досліджуваних монетах із родовими гербами київських князів X-XI ст. Чітка просторова орієнтація цього геральдичного елементу наслідувань ставить під сумнів усталену в нумізматиці думку щодо просторової орієнтації «князівського знаку» на київських денаріях Володимира Ольгердовича та дозволяє порушити питання про їі деяку корекцію.

\section{REFERENCES}

Antonovich, V. B. (1878). O novonajdennyh serebrjanyh monetah s imenem Vladimira. [About newly found silver coins with the name of Vladimir.] Trudy III Arheologicheskogo sezda. Vol. 2. (pp.151-157). Kiev. [in Russian].

Bektineev, Sh. (1994). Denezhnoe obrashhenie Velikogo knjazhestva Litovskogo v XIII$X V v v$. [Money circulation of the Grand Duchy of Lithuania during the XIII-XV centuries.]. Minsk: V. N. Miljutin. [in Russian].

Bolsunovskij, K. V. (1909). Monety kievskih knjazej XIV stoletija. [Coins of the Kiev princes of the XIV century]. Kiev: Tipo-litografija "Progress". [in Russian].

Guleckij, D. V., \& Petrunin, K. M. (2013). Russkie monety 1353-1533. Katalog. [Russian coins 1353-1533. Catalog.]. Minsk: RIFTUR. [in Russian].

Dubickaja, V. (2012). Novye dannye po atribucii $i$ datirovke monet Kievskogo knjazhestva (po rezul'tatam poshtempel'nyh svjazej). [New data on the attribution and dating of coins of the Principality of Kiev (based on the results of stamp links)]. Abstracts of Papers. Mezhdunarodnaja numizmaticheskaja konferencija. (pp. 112-115). Vil'njus. [in Russian].

Il'in, A. A. (1940). Klassifikacija russkih udel'nyh monet [Classification of coins of Russian apanage principalities]. Leningrad: Gos. Jermitazh. [in Russian].

Kozubovskij, G. A. (1991). Nahodki monet na territorii Kieva [Finds of coins in the territory of Kiev]. Kiev. [in Russian].

Kozubovskyi, H. A. (2016). Do khronolohii karbuvannia monet Volodymyra Olherdovycha (1362-1394) [On the coinage chronology of Volodymyr Olgerdovych (13621394)]. Arkheolohiia, 4, 27-41. [in Ukrainian].

Kotljar, N. F. (1970). Klad monet Vladimira Ol'gerdovicha [Treasure of coins of Vladimir Olgerdovich]. Numizmatika i jepigrafika, (VIII), 88-100. [in Russian].

Kotljar, N. F. (1971). Monety Vladimira Ol'gerdovicha [Coins of Vladimir Olgerdovich]. Numizmatika i sfragistika, (IV), 42-67. [in Russian].

Klymovskyi, S. (2007). Kyivski monety Volodymyra Olherdovycha: priorytet polityky chy ekonomika? [Kyiv coins of Volodymyr Olgerdovych: priority of politics or economy?]. Istoryko-heohrafichni doslidzhennia v Ukraini, (10), 358-375. [in Ukrainian].

Petrov, N. I. (1908). O novootkrytoj kievskoj monete XIV veka [About the newly discovered Kiev coin of the XIV century]. Sbornik Har'kovskogo istoriko-filologicheskogo obshhestva, (VIII), 1-6. [in Russian].

Pohorilets, O., \& Savvov, R. (2009). Pro novi monety zi znakom Volodymyra Olherdovycha [About new coins with the mark of Volodymyr Olgerdovych]. Numizmatyka $i$ falerystyka,1, 10-11. [in Ukrainian].

Potyl'chak, O. V. (2019). Ridkisnyi typ nasliduvannia dyrkhemu khana Toktamysha z kniazivskym znakom Volodymyra Olherdovycha [A rare type of inheritance of Khan Toktamysh's Dirhem with the princely mark of Volodymyr Olgerdovych]. Abstracts of Papers: Kulturnoistorychna spadshchyna Ukrainy: perspektyvy doslidzhennia ta tradytsii zberezhennia: materialy II Vseukrainskoi naukovo-praktychnoi konferentsii. (pp. 7-9). Cherkasy. [in Ukrainian]. 
Potyl'chak, O. V. (2019). Neopysanyi typ nasliduvannia Dzhuchydskym dyrkhemam kintsia XIV stolittia: do problemy atrybutsii numizmatychnoi pamiatky [The Unspecified Type of Imitation of the Juchid Dirhems of the End of the Fourteenth Century: Towards the Problem of Attribution of a Numismatic Monument]. Abstracts of Papers: Naukova atrybutsiia tvoriv mystetstva, ekspertyza ta otsinka kulturnykh tsinnostei. (pp. 120-124). Kyiv. [in Ukrainian].

Rusyna, O. V. (1998). Ukraina pid tataramy i Lytvoiu [Ukraine under the Tatars and Lithuania]. Kyiv: Vydavnychyi dim "Alternatyvy". [in Ukrainian].

Savvov, R. (2012). Kyivski pivhroshi Volodymyra Olherdovycha [Kyiv half-pennies of Volodymyr Olgerdovych]. Numizmatyka i falerystyka, 4, 6-7. [in Ukrainian].

Soboleva, N. A. (1970). K voprosu o monetah Vladimira Ol'gerdovicha (po numizmaticheskim materialam GIM) [On the issue of Vladimir Olgerdovich's coins (based on numismatic materials from the State Historical Museum)]. Numizmatika i jepigrafika, (VIII), 81-87. [in Russian].

Tolstoj, I. I. (1882). Drevnejshie russkie monety Velikogo knjazhestva Kievskogo: numizmaticheskij opit [The oldest Russian coins of the Grand Duchy of Kiev: numismatic experience]. Sankt-Peterburg: Tipografija Imperatorskoj akademii nauk. [in Russian].

Trost'janskij, O. V., \& Leonov, O. V. (2016). Novyj tip monet Kievskogo knjazhestva konca XIV v. [A new type of coins of the Principality of Kiev at the end of the 14th century]. Numizmatika Zolotoj Ordy: Nauchnyj ezhegodnik, (6), 95-97, 156.

Hromov, K. K. (2007). O monetnoj chekanke na territorii Kievskogo knjazhestva v 50-e gody XIV veka [About coinage on the territory of the Kiev principality in the 50s of the $14^{\text {th }}$ century]. Vostochnaja numizmatika v Ukraine, (II), 60-79.

Khromov, K., \& Khromova, I. (2015). Mistsevi monety-nasliduvannia druhoi polovyny $X I V$ st. na lytovsko-ordynskykh prykordonnykh terytoriiakh [Local coin-imitation of the second half of the 14th century in the Lithuanian-Horde border areas]. Ukraina Lithuanica, (3), 191203. [in Ukrainian].

Khromova, I. (2008). Do problemy atrybutsii zobrazhennia rodovoho znaku kniaziv Olherdovychiv [To the problem of attribution of the image of the generic sign of the princes Olgerdovych]. Spetsialni istorychni dystsypliny: pytannia teorii ta metodyky, (15), 304-315. [in Ukrainian].

Khromova, I. (2009). Do pytannia pro vplyv dzhuchydskoi monetnoi tradytsii na formuvannia mistsevoi monetnoi spravy v ukrainskomu Podniprovi seredyny druhoi polovyny $X I V$ st. [To the question of the influence of the Juchid mint tradition on the formation of local mint in the Ukrainian Dnieper in the middle of the second half of the 14th century]. Ukrainskyi istorychnyi zbirnyk, (12), 49-59. [in Ukrainian].

Khromova, I. (2010). Sosnytskyi skarb: do pytannia analizu ta klasyfikatsii monet Volodymyra Olherdovycha [Sosnitsky treasure: on the issue of analysis and classification of coins of Volodymyr Olgerdovych]. Ukrainskyi istorychnyi zbirnyk, (13), 22-43. [in Ukrainian].

Khromova, I. K. (2011). Nasliduvannia monet Chervonoi Rusi z Serednoho Podniprovia [Red Russia coins-imitation from the territory of the Middle Dnieper]. Spetsialni istorychni dystsypliny: pytannia teorii ta metodyky, (18), 222-225. [in Ukrainian].

Khromova, I. (2012). Monetne karbuvannia na terytorii Serednoho Podniprovia vid nasliduvan do ofitsiinykh emisii: pytannia ikonohrafii [Coinage in the territory of the Middle Dnieper from imitation to official emissions: iconography issues]. Ukrainskyi istorychnyi zbirnyk, (15), 229-237. [in Ukrainian].

Hromova, I., \& Hromov, K. (2012). Voprosy atribucii nahodok mestnyh monetpodrazhanij vtoroj poloviny XIV veka na territorii litovsko-ordynskogo pogranich'ja [Issues of attribution of the finds of local imitation coins of the second half of the 14th century on the 
territory of the Lithuanian-Horde borderland]. Abstracts of Papers: Mezhdunarodnaja numizmaticheskaja konferencija. Vil'njus. URL: www.hordecoins.folgat.net/Rpubl_Vilnusconf-2012.htm [in Russian].

Khromova, I. (2013). Do istorii rozvytku karbuvannia na ukrainskykh zemliakh: mistsevi nasliduvannia dzhuchydskykh monet XIV st. [Towards a History of Coinage Development in Ukrainian Lands: Local Imitation of Juchid Coins (XIV century)]. Spetsialni istorychni dystsypliny: pytannia teorii ta metodyky, (22-23), 462-470. [in Ukrainian].

Khromova, I. (2017). "Kniazivska symvolika” u monetnomu karbuvanni XIV-pochatku $X V$ st. $z$ terytorii Serednoho Podniprovia ["Prince's symbolism" in the coinage of the XIV early XV centuries from the territory of the Middle Dnieper]. Ukrainskyi istorychnyi zbirnyk, (19), 41-52. [in Ukrainian].

Cherkas, B. (2013). Zakhidni volodinnia Zolotoi Ordy v 1380-1399 rr. (politychnyi aspekt) [Western Possessions of the Golden Horde in 1380-1399 (political aspect)]. Ukraina v Tsentralno-Skhidnii Yevropi, (12-13), 197-204. [in Ukrainian].

Gumowski, M. (1921). Numizmatyka litewska wieków srednich [Lithuanian Numismatics of the Middle Ages]. Wiadomości Numizmatyczno-Archeologiczne, (XIX), 55-106. [in Polish].

\section{ІЛЮСТРАЦІї}
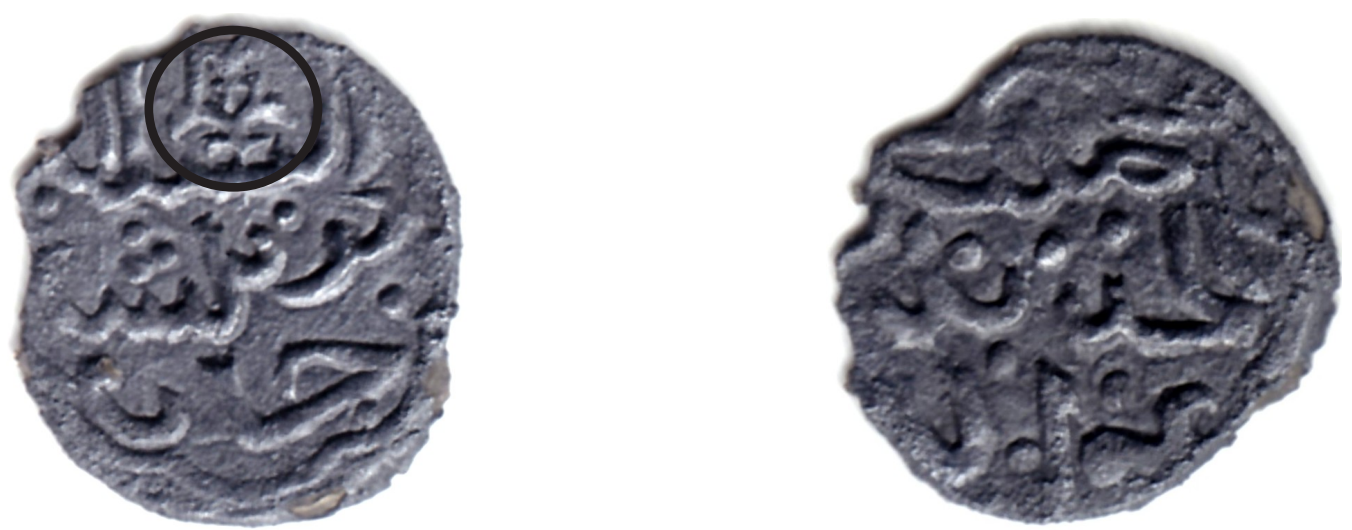

Puc. 1.

Наслідування дирхема Токтамиша з «князівським знаком» Володимира Ольгердовича. Вінницькі Стави Васильківського р-ну Київської обл. [Архів ННЛ ЕКІЦ НПУ імені М. П. Драгоманова. Фонд 2. Польові описи експедицій. Опис 1. Справа 1. Польовий опис постійно діючої нумізматичної експедиції за темою «Грошовий обіг Правобережної України у XVI-XVIII ст.ст. (регіон Південної Київщини та Середнього Поросся)». 2016-2018 рр. Арк. 10.]. Зображення збільшено.
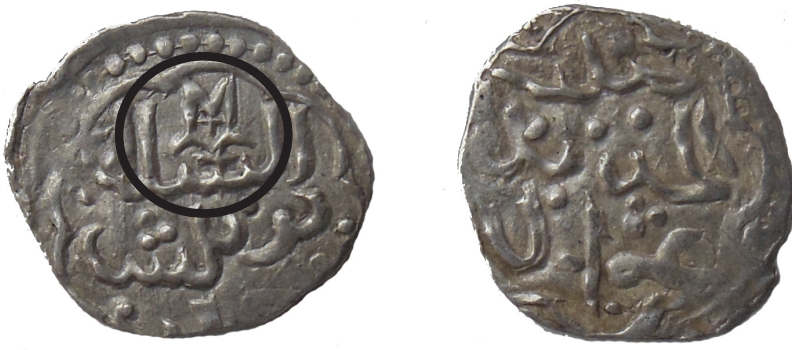

Puc. 2.

Наслідування дирхема Токтамиша 3 «князівським знаком» Володимира Ольгердовича. Україна.

Обставини та місце знахідки невідомі

[Тростьянский О. В., Леонов Б. И. Указ. соч. С. 156]. Зображення збільшено.
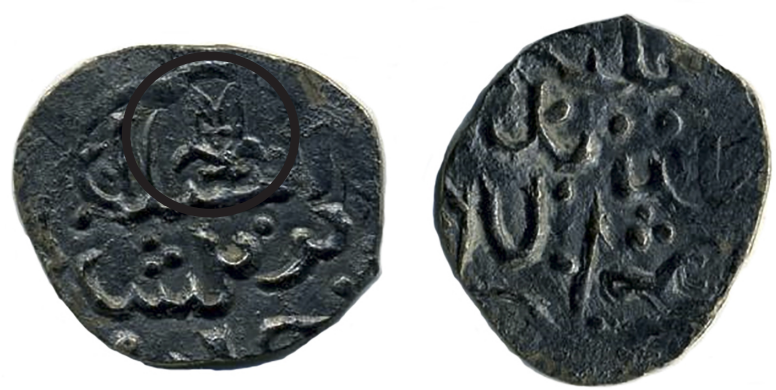

Puc. 3.

Наслідування дирхема Токтамиша 3 «князівським знаком» Володимира Ольгердовича. Клімовський р-н Брянської обл., РФ. Зображення збільшено. [Тростьянский О. В., Леонов Б. И. Указ. соч. С. 156] 


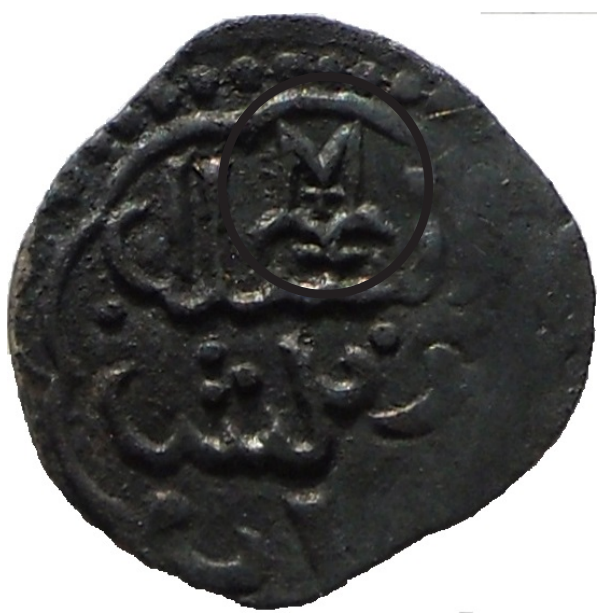

Puc. 4.

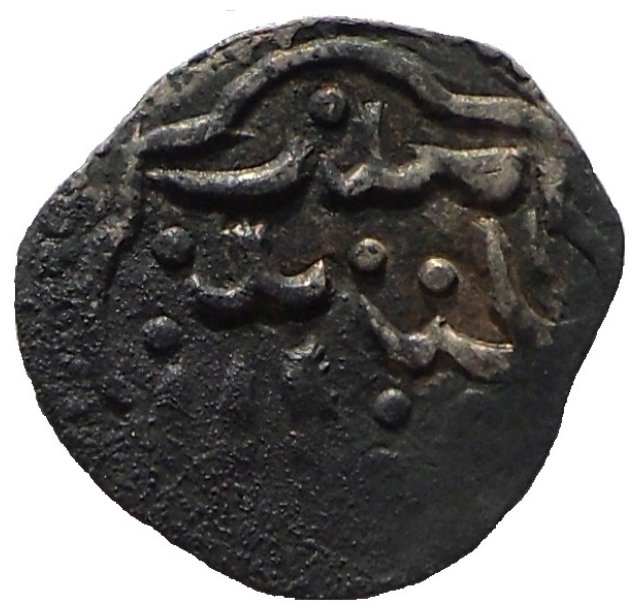

Наслідування дирхема Токтамиша 3 «князівським знаком» Володимира Ольгердовича. Хорольський р-н Полтавської обл. Публікується вперше. Світлину надано автору О. В. Тростьянським. Зображення збільшено.

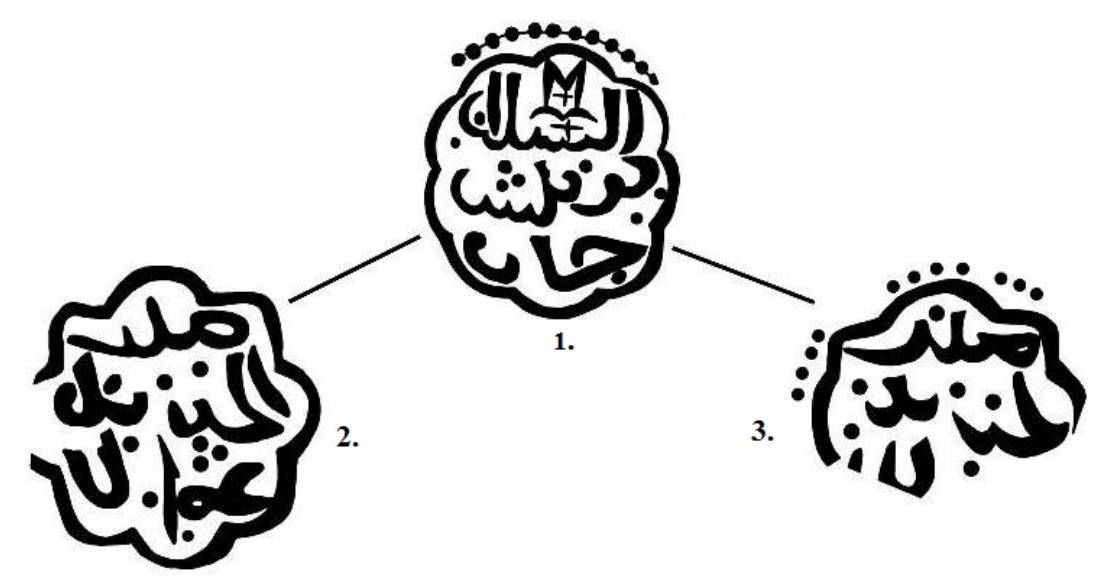

Puc. 5.

Абриси штемпеля аверсу (1) та варіантів реверсу $(2,3)$ наслідувань дирхема Токтамиша 3 «князівським знаком» Володимира Ольгердовича [Авторка реконструкцій О. В. Тростьянська, 2019 р.]

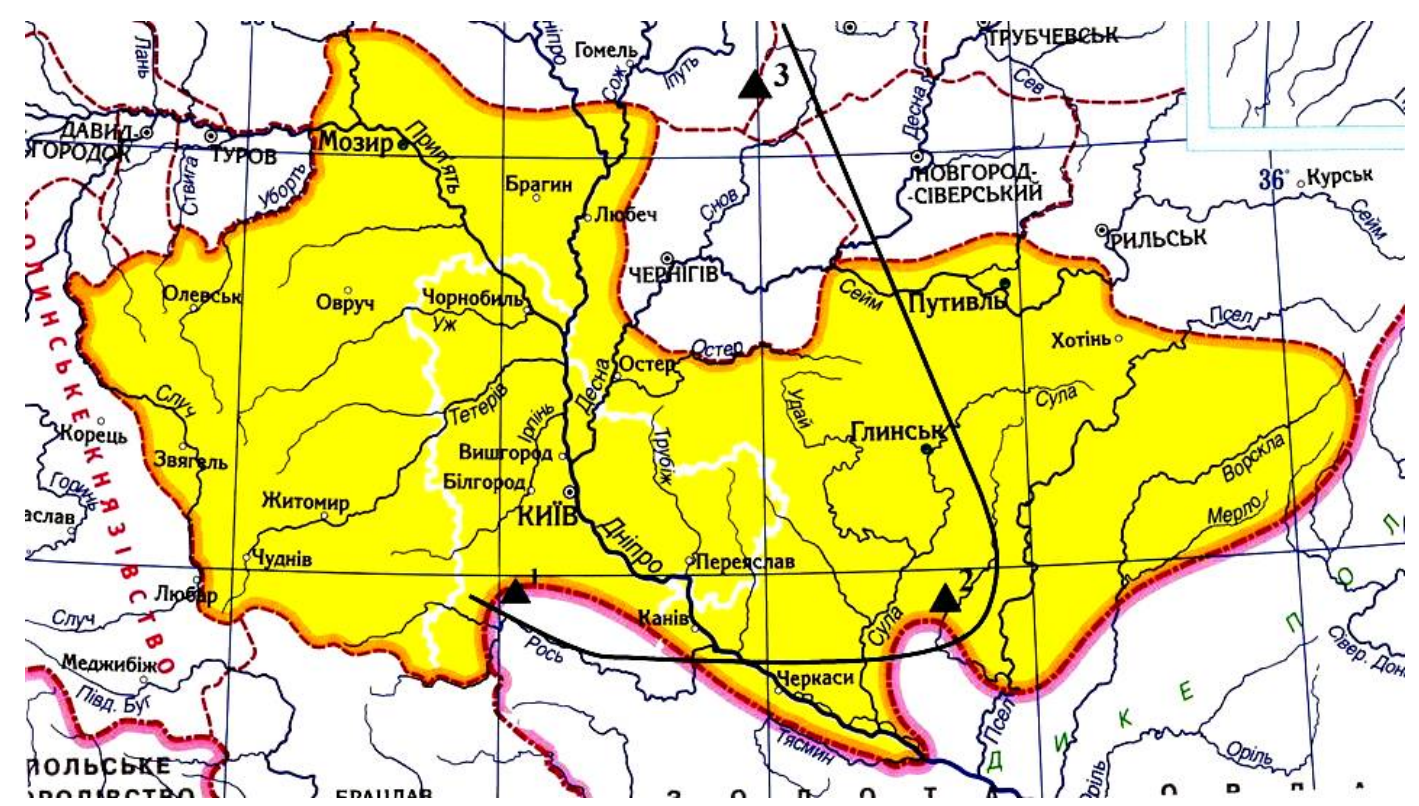

Puc. 6.

Карта-схема 1. Локалізація знахідок наслідувань дирхемів з «князівським знаком» Володимира Ольгердовича

(1 - Вінницькі Стави Васильківського р-ну Київської обл.; 2 - Хорольський р-н Полтавської обл.; 3 - Клімовський р-н Брянської обл., РФ) 